\title{
MENGENAL SPINA BIFIDA DAN PENCEGAHANNYA
}

\author{
Genta Faesal Atsani, Zanetha Mauly Ilawanda, Ilma Fahira Basyir \\ Fakultas Kedokteran, Universitas Mataram, Indonesia. \\ Email: zanethailawanda@gmail.com,gentafaesal16@gmail.com, \\ ilma.fakhira@gmail.com
}

\begin{abstract}
Abstrak
Neural tube defects (NTD) adalah salah satu cacat lahir atau kelainan bawaan yang terjadi pada otak dan tulang belakang dan paling sering terjadi pada bayi baru lahir di seluruh dunia. Insiden spina bifida terjadi rata-rata 1 dari 1000 kasus kelahiran di seluruh dunia dan ada 140.000 kasus per tahun di seluruh dunia. Pencarian sumber dilakukan di portal online publikasi jurnal sebanyak 20 sumber yang berasal dari MedScape, Google Scholar dan Nation Center for Biotechnology Information/ NCBI dengan kata kunci "Neural tube defects (NTD), prevention, and spina bifida". Spina bifida adalah kelainan bawaan yang terjadi di dalam rahim akibat kegagalan menutup tabung saraf selama beberapa minggu pertama perkembangan embrio yang mengakibatkan tulang belakang tidak menutup sempurna di sekitar saraf sumsum tulang belakang yang sedang berkembang. NTD dapat disebabkan karena kondisi multifaktorial seperti genetik, lingkungan, dan kekurangan asam folat. Penggunaan suplementasi asam folat yang dimulai minimal 3 bulan sebelum kehamilan yaitu $400 \mathrm{mcg}(0,4 \mathrm{mg})$ per hari dan $800 \mathrm{mcg}$ per hari selama hamil dapat menurunkan risiko terjadinya cacat tabung saraf seperti spina bifida. Penatalaksanaan spina bifida secara umum terdiri dari pembedahan dan penanganan keluhan penyerta pasien. Masyarakat diharapkan dapat mengetahui pencegahan untuk menghindari atau mengurangi risiko kejadian spina bifida sehingga menurunkan angka kejadian dan meningkatkan kesadaran masyarakat tentang penyakit ini.
\end{abstract}

Kata Kunci: "Neural tube defects (NTD), pencegahan, dan spina bifida".

\section{Abstract}

Neural tube defects (NTD) are one of the birth defects or congenital abnormalities that occur in the brain and spine, and commonly find in newborns worldwide. Anencephaly and spina bifida are the two prevalent forms of NTD. The incidence of spina bifida happen on average 1 in 1000 cases of birth worldwide and there are 140,000 cases per year worldwide. Source searches were carried out on the online portal of journal publications as many as 20 sources from MedScape, Google Scholar and the Nation Center for Biotechnology Information / NCBI with the keywords "Neural tube defects (NTD), prevention, and spina bifida". Spina bifida is a congenital abnormality that occurs in the womb due to a failure of closing process the neural tube during the first few weeks of embryonic development which causes the spine not 
completely close around the developing spinal cord nerves. NTD can ensue multifactorial conditions such as genetic, environmental, and folate deficiency. The use of folic acid supplementation starting at least 3 months before pregnancy, those are $400 \mathrm{mcg}(0.4 \mathrm{mg})$ per day and $800 \mathrm{mcg}$ per day during pregnancy can reduce the risk of developing neural tube defects such as spina bifida. Generally, spina bifida is undertaking by surgery and the regulation of patients comorbid. Public can find out prevention to avoid or reduce the risk of spina bifida so that the incidence of spina bifida can decrease along with the increasing awareness of the community regarding this disease.

Keywords: "Neural tube defects (NTD), prevention, and spina bifida".

Diterima: 08-11-2021 Derevisi: 11-12-2021_Diteritkan: 20-12-2021

\section{Pendahuluan}

Neural tube defects (NTD) adalah salah satu cacat lahir atau kelainan bawaan yang terjadi pada otak dan tulang belakang dan paling umum terjadi pada bayi baru lahir di seluruh dunia. NTD merupakan kelainan kongenital yang terjadi akibat kegagalan penutupan lempeng saraf (neural plate) (WHO, 2007). Kelainan yang termasuk dalam NTD yaitu anencephaly, encephalocele, meningocelekranial, myelomenigocele, spinal meningocele, lipomeningocele, dan spina bifida. Anencephaly dan spinda bifida merupakan dua bentuk NTD yang paling umum dan dilaporkan terjadi pada 300.000 atau lebih bayi yang baru lahir di seluruh dunia setiap tahunnya (WHO/CDC/ICBDSR, 2014).

Spina bifida adalah kelainan bawaan yang terbentuk sejak dalam kandungan yang terjadi karena adanya kegagalan penutupan tabung saraf selama beberapa minggu pertama perkembangan embrio yang mengakibatkan tulang belakang tidak menutup sepenuhnya disekitar saraf sumsum tulang belakang yang sedang berkembang (Brea \& Munakomi, 2021). Spina bifida merupakan salah satu kelainan kongenital yang sering terjadi pada bayi baru lahir setelah anencephaly dan ensefalus. Di Indonesia, kelainan bawaan yang paling banyak ditemukan adalah dari kelompok sistem muskulo skeletal (talipes), sistem saraf (anenchepali, spina bifida dan meningochele), celah bibir dan langit-langit dan omphalocele (Kemenkes, 2016).

Anak yang lahir dengan spina bifida memiliki kantung berisi cairan di punggungnya yang ditutupi oleh kulit. Anak dengan spina bifida sering mengalami masalah pada tulang belakang dan otak yang menyebabkan tidak dapat merasakan apapun pada kaki, tangan sehingga memiliki keterbatasan dalam melakukan aktivitas untuk bergerak, kehilangan fungsi berkemih dan buang air besar, serta penumpukan cairan pada otak (hydrocephalus) (Mitchell et al., 2014). Menurut penelitian, spina bifida disebabkan oleh multifaktorial dan salah satu faktor yang berkontribusi terhadap terjadinya spina bifida adalah kekurangan asam folat yang dikonsumsi ibu selama kehamilan (Ernawati, 2011). Central for Disease Control (CDC) merekomendasikan semua wanita usia subur untuk mengonsumsi 400 mikrogram asam folat setiap hari untuk membantu mencegah terjadinya neural tube defect (NTD). Semua perempuan 
yang merencankan kehamilan direkomendasikan untuk mengonsumsi suplemen asam folat harian setidaknya satu bulan sebelum konsepsi sampai trimester pertama (WHO/CDC/ICBDSR, 2014).

\section{Metode Penelitian}

Penelitian ini menggunakan metode kualitatif dengan bersumber dari jurnal ilmiah, pedoman pemerintah dan instansi terkait yang fokus pada stroke dan karakteristik radiologisnya. Di portal online publikasi jurnal, pencarian sumber dari hingga 20 sumber dari MedScape, Google Scholar (scholar.google.com) dan National Center for Biotechnology Information/NCBI (ncbi.nlm.nih.gov) dilakukan, Dan menggunakan kata kunci "neural tube defect (NTD), pencegahan dan spina bifida".

\section{Hasil dan Pembahasan}

\section{Definisi}

Spina bifida merupakan isitilah kelainan kongenital, yakni tulang belakang mengalami pembelahan (bifid) akibat kegagalan penutupan tabung saraf pada minggu keempat fase embrionik. Dalam beberapa kasus sering ditemukan berupa myelomeningocele (MMC) atau dikenal dengan spina bifida terbuka atau spina bifida aperta. Individu yang terkena spina bifida biasanya menunjukan gejala defisit neurologic sensorik dan motorik, sehingga menyebabkan kelemahan atau kelumpuhan pada tungkai, inkontinensia, dan herniasi pada sistem saraf pusat (Copp et al., 2015).

\section{Epidemiologi}

Insiden spina bifida rata-rata terjadi 1 dari 1000 kasus kelahiran diseluruh dunia, dengan asumsi populasi global 7 miliar dengan angka kelahiran 20 per 1000 penduduk, maka diperoleh angka 140.000 kasus pertahun diseluruh dunia. Kejadian ini bervariasi berdasarkan letak geografis, insiden tertinggi dilaporkan terjadi di kepulauan Inggris, terutama Irlandia dan Wales, dimana insiden rata-rata yang dilaporkan sekitar 3-4 kasus per 1000 populasi (Copp et al., 2015).

\section{Etiologi}

Etiologi spina bifida belum diketahui secara pasti. Seperti berbagai kelainan lainnya, penyakit ini diduga disebabkan oleh kombinasi dari faktor genetik dan lingkungan. Faktor lingkungan yang utama, yaitu kekurangan folat. Faktor lingkungan lain, yaitu obesitas ibu, diabetes ibu, dan teratogen (Panda, 2019). Faktor genetik dapat terjadi pada sindrom kromosom dan polimorfisme genetik (Brea \& Munakomi, 2021). Beberapa penjelasan faktor yang dikaitkan dengan peningkatan risiko spina bifida adalah

1. Defisiensi folat. Folat (vitamin B9) Ini sangat penting untuk perkembangan kesehatan bayi. Asam folat adalah bentuk alami vitamin B9. Jenis sintetis yang ditemukan dalam suplemen dan makanan yang diperkaya adalah asam folat. Kekurangan asam folat meningkatkan risiko spina bifida dan cacat tabung saraf lainnya (Brea \& Munakomi, 2021). 
2. Riwayat keluarga dengan cacat tabung saraf. Pasangan yang memiliki anak dengan cacat tabung saraf memiliki peluang sedikit lebih tinggi untuk memiliki anak lagi dengan cacat yang sama. Pasangan dengan dua anak dengan cacat tabung saraf berada pada peningkatan risiko (Mayo, 2018).

3. Mengkonsumsi obat-obatan tertentu selama kehamilan. Mengambil jenis obat tertentu selama kehamilan, seperti jenis obat anti-epilepsi tertentu, dikaitkan dengan risiko cacat tabung saraf. Hal ini diduga terkait dengan kemampuan tubuh untuk menggunakan asam folat dan asam folat (Sacco, 2019).

4. Diabetes. Wanita dengan diabetes dan kadar gula darah yang tidak terkontrol berisiko lebih tinggi melahirkan bayi dengan spina bifida (Anon., 2017).

5. Obesitas. Obesitas sebelum kehamilan meningkatkan risiko cacat tabung saraf, termasuk spina bifida pada bayi (Rochtus, et al., 2017).

6. Peningkatan suhu tubuh. Beberapa penelitian ilmiah telah menunjukkan bahwa kenaikan suhu tubuh dalam beberapa minggu pertama kehamilan meningkatkan risiko spina bifida pada bayi (Chen, et al., 2018).

7. Peningkatan suhu tubuh akibat demam, menggunakan sauna, atau mandi air panas, dikaitkan dengan kemungkinan peningkatan risiko terjadinya spina bifida pada bayi (Lemay, et al., 2017).

\section{Pencegahan}

Salah satu penyebab NTD adalah defisiensi asam folat. Banyak sekali kasus defisiensi asam folat yang tidak terdiagnosis. Sehingga dibutuhkannya suplementasi asam folat yang adekuat pada Ibu hamil. Asupan folat yang memadai sangat penting bahkan sebelum pembuahan, disebabkan karena pembelahan sel terjadi cepat pada harihari pertama dan minggu awal masa kehamilan. Adapun sumber-sumber yang kaya akan asam folat seperti ragi, hati, sayur-sayuran berwarna hijau, kembang kol, brokoli, daging, susu, ikan, dan buah-buahan (Wulan dan Simanjuntak, 2016).

Penggunaan suplementasi asam folat dimulai setidaknya 3 bulan sebelum kehamilan yaitu $400 \mathrm{mcg}(0,4 \mathrm{mg})$ per hari dan $800 \mathrm{mcg}$ per hari selama kehamilan. Penggunaan suplemen asam folat ini penting untuk menurunkan risiko terjadinya defek neural tube seperti spina bifida (Ernawati, 2011; Rofi'atunnisa', 2020). Selain suplementasi asam folat, direkomendasikan juga untuk mengkonsumsi makanan seimbang dengan berbagai vitamin, mineral, serat, dan protein disamping energi yang diperlukan untuk aktivitas sehari-hari (Rofi'atunnisa', 2020).

\section{Tatalaksana}

Penatalaksanaan spina bifida secara umum terdiri dari pembedahan dan penanganan gejala-gejala penyerta penderita.

A. Pembedahan

1. Operasi Pasca Lahir

Pembedahan adalah pengobatan utama untuk kasus spina bifida dan harus dilakukan dalam waktu 48 jam setelah kelahiran. Penutupan penyakit spina bifida adalah untuk melindungi sumsum tulang dan saraf serta mencegah meningitis. Semakin cepat operasi penutupan dilakukan, semakin baik perlindungan organ. 
Pembedahan tidak dapat memperbaiki atau mengganti saraf yang rusak (Mohd-Zin et al., 2017).

Luka spina bifida ditutup dengan lipatan kulit dan otot atau tambalan sintetis yang terbuat dari gelatin, kolagen, dll. Pembedahan juga bisa dilakukan saat janin masih dalam kandungan. Selain mencegah kerusakan saraf, tujuan operasi prenatal adalah untuk mencegah kebocoran cairan serebrospinal (CSF).

2. Operasi Janin

Operasi pada janin dapat dilaksanakan pada usia kehamilan 19-25 minggu. Operasi prenatal memiliki risiko, seperti kelahiran prematur, ketuban pecah dini, dan peningkatan risiko kematian janin dan bayi baru lahir. (Phillips, Burton and Evans, 2017).

B. Penanganan gejala-gejala

1. Sistem Saraf

Ventrikulomegali dan hidrosefalus kerap kali dijumpai sebagai penyakit penyerta penderita spina bifida. Penanganan operatif untuk menangani komorbid ini, antara lain:

a. Koagulasi pleksus koroid untuk mencegah produksi cerebrospinal fluid (CSF) yang dapat memperparah kondisi hidrosefalus

b. Membuat shunt ventrikuloperitoneal untuk membantu aliran CSF

c. Ventrikulostomi pada ventrikel 3 untuk membantu aliran CSF dan mengurangi hidrosefalus (Copp et al., 2015).

2. Sistem Saluran Kemih

Kateterisasi intermiten, terapi medikamentosa, dan operasi merupakan tata laksana terkait komorbid saluran kemih. Tujuan pengobatan awal adalah untuk mempertahankan fungsi ginjal. Dengan bertambahnya usia, kontrol buang air kecil, buang air besar dan fungsi seksual menjadi tujuan manajemen. Obat-obatan, seperti penggunaan antikolinergik dan kateter, didasarkan pada temuan klinis dari tes urodinamik, yang menunjukkan perburukan atau hidronefrosis. Jika perawatan medis gagal untuk meningkatkan kualitas hidup anak-anak melalui buang air kecil dan fungsi tinja yang independen dan terkontrol, pembedahan diperlukan. (SnowLisy, Yerkes and Cheng, 2015).

3. Otot dan Tulang

Semakin tinggi lokasi lesi, semakin banyak otot yang abnormal, semakin parah kelemahan penderita spina bifida. Pasien sering mengalami ketidakseimbangan dan kelainan ortopedi, seperti displasia pinggul, varus tapal kuda, dan talus vertikal. Penggunaan orthotic dan pembedahan adalah perawatan pilihan untuk kondisi ini. Operasi korektif dapat dilakukan setelah lahir, membutuhkan tindak lanjut jangka panjang (Copp et al., 2015).

4. Kulit

Kondisi pressure ulcer sering dialami oleh penderita terkait dengan penggunaan kursi roda akibat kelemahan motorik yang dialami. Untuk 
menghindarinya, perlu mengubah posisi setiap 10-15 menit. Selain itu, gangguan sensorik pada area kulit juga dapat menyebabkan pasien mengalami luka bakar, yang dapat ditangani sesuai dengan kedalaman lukanya. Obat topikal seperti bacitracin, perak sulfadiazin, dan perak nitrat dapat digunakan. Namun, perlu dicatat bahwa pasien di bawah usia 2 tahun tidak boleh menggunakan sulfadiazin perak karena meningkatkan risiko kernikterus. (Phillips, Burton and Evans, 2017).

\section{Kesimpulan}

Berdasarkan uraian diatas dapat disimpulkan bahwa Neural Tube Defects (NTD) adalah salah satu cacat lahir atau kelainan bawaan yang terjadi pada otak dan tulang belakang dan paling umum terjadi pada bayi baru lahir di seluruh dunia. Spina bifida merupakan salah satu kasus NTD yang paling sering terjadi dengan angka kejadian spina bifida rata-rata terjadi 1 dari 1000 kasus kelahiran di seluruh dunia dan ada 140.000 kasus per tahun di seluruh dunia. Diharapkan dengan adanya artikel ini masyarakat bisa lebih mengenali faktor resiko terjadinya spina bifida seperti kekurangan asam folat, obesitas, diabetes, dan dapat segera melakukan skrining pada saat kehamilan. Selain itu masyarakat dapat mengetahui pencegahan untuk mencegah atau mengurangi resiko terjadinya spina bifida sehingga angka kejadian spina bifida dapat terus menurun seiring dengan timbulnya kesadaran pada masyarakat terkait penyakit ini.

Untuk kedepannya penulis menyarankan kepada masyarakat dapat melakukan pencegahan spina bifida dengan cara konsumsi asam folat pada saat sebelum dan selama kehamilan, serta menyarankan kepada penulis lain diluar sana untuk memberikan informasi lebih lanjut mengenai dampak yang akan terjadi pada anak yang mengalami spina bifida agar dapat mengurangi resiko jangka panjang seperti kegagalan dalam pertumbuhan dan perkembangan anak di masa yang akan datang. Sehingga hal tersebut dapat memberikan gambaran lebih luas kepada masyarakat agar lebih waspada dengan melakukan tindakan pencegahan terhadap penyakit ini. 
Genta Faesal Atsani, Zanetha Mauly Ilawanda, Ilma Fahira Basyir

\section{BIBLIOGRAFI}

Anon., 2017. National Health Service UK. Health A-Z. Spina bifida. Google Scholar

Anon., 2019. Centers for Disease Control and Prevention. Spina Bifida. Google Scholar

Anon., n.d. WebMD.com. Diakses pada 2019. Spina Bifida.. Causes, Symptoms, Diagnoses, and Treatment. Google Scholar

Brea, C. M. \& Munakomi, S., 2021. Spina Bifida. [Online] Available at: https://www.ncbi.nlm.nih.gov/books/NBK559265/ [Accessed 20 April 2021]. Google Scholar

Chen, S., Zhang, Q. \& Bai, B., 2018. A Common Variant in MTHFD1L is Associated with Increased Risk for Spina Bifida. Journal of Molecular and Clinical Medicine, pp. 1(1):19-22.. Google Scholar

Copp, A. J. et al. (2015) 'Spina bifida', Nature Reviews Disease Primers, 1(April), pp. 1-18. doi: 10.1038/nrdp.2015.7. Google Scholar

Cristina M. Brea; Sunil Munakomi (2021) 'Spina Bifida', in. StatPearls. Google Scholar

Ernawati (2011) 'Spina Bifida', Jurnal Ilmiah Kedokteran Wijaya Kusuma, I(1), pp. 19-23. Google Scholar

Gao, Y.-j.et al., 20. Clinical features and outcomes of pregnant women with COVID-19: a systematic review and meta-analysis. BMC Infectious Diseases. Google Scholar

Handayani, R. T. et al., 2020. Infeksi Covid-19 Pada Kehamilan Dan Persalinan. Jurnal Informasi Kesehatan Indonesia. Google Scholar

Kemenkes (2016) 'Hasil Surveilans Kelainan Bawaan'. Google Scholar

Kemenkes RI, 2018. Direktorat Pencegahan Dan Pengendalian Penyakit Tidak Menular. [Online] Available at: http://p2ptm.kemkes.go.id/infographic$\mathrm{p} 2 \mathrm{ptm} /$ stroke/faktor-risiko-stroke-yang-bisa-diubah

Lemay, P., De, M. \& , 2017. Rare deleterious variants in GRHL3 are associated with human spina bifida. Human Mutation., pp. 38(6):716-724.. Google Scholar

Mayo, C., 2018. Diseases \& Conditions.. Spina bifida.. Google Scholar

Mitchell, L. E. et al. (2014) 'Spina bifida', Cambridge Handbook of Psychology, Health and Medicine, Second Edition, pp. 889-891. doi: 10.1017/CBO9780511543579.237. Google Scholar

Mohd-Zin, S. W. et al. (2017) 'Spina Bifida: Pathogenesis, Mechanisms, and Genes in Mice and Humans', Scientifica, 2017. doi: 10.1155/2017/5364827. Google Scholar

Nurdianto, Rohmah, M. K. \& Rahman, A., 2020. Corona Virus Disease 2019 (COVID19) pada Wanita Hamil dan Bayi: Sebuah Tinjauan Literatur. Medica Hospital Journal of Clinical Medicine. Google Scholar

Panda, e. a., 2019. Molecular Basis of Spina Bifida: Recent Advances and Future Prospectives.. Journal of Pediatric Neurosciences, pp. 14(1), pp. 16-19.. Google Scholar 
Phillips, L. A., Burton, J. M. and Evans, S. H. (2017) 'Spina Bifida Management', Current Problems in Pediatric and Adolescent Health Care, 47(7), pp. 173-177. doi: 10.1016/j.cppeds.2017.06.007. Google Scholar

Rochtus , A., Winand, R. \& Izzi, B., 2017. Methylome analysis for spina bifida shows SOX18 hypomethylation as risk factor with evidence for a complex (epi)genetic interplay to affect neural tube development.. European Journal of Paediatric Neurology. , pp. 21:e45-e46.. Google Scholar

Rofi'atunnisa' (2020) 'Suplementasi Folat Dapat Menurunkan Risiko Cacat Tabung Saraf Pada Janin', Jurnal Penelitian Perawat Profesional, 2(November), pp. 371-380. Google Scholar

Romadhoni, W. N. et al., 2020. Pentingnya Pola Makan Bergizi dan Seimbang di Era Pandemi COVID-19. Google Scholar

Sacco, 2019. Fetal Surgery for Open Spina Bifida. The Obstetrician \& Gynaecologist, pp. 21(4), pp. 271-282.. Google Scholar

Satuan Gugus Tugas COVID-19, 2021. Peta Sebaran COVID-19. [Online] Available at: https://covid19.go.id/peta-sebaran-covid19

Snow-Lisy, D. C., Yerkes, E. B. and Cheng, E. Y. (2015) 'Update on Urological Management of Spina Bifida from Prenatal Diagnosis to Adulthood', Journal of Urology, 194(2), pp. 288-296. doi: 10.1016/j.juro.2015.03.107. Google Scholar

WHO/CDC/ICBDSR (2014) 'Birth defects surveillance: atlas of selected congenital anomalies', WHO Library Cataloguing-in-Publication Data, pp. 1-28. Google Scholar

WHO (2007) 'Standards for Maternal and Neonatal Care', WHO Library, pp. 1-72. Google Scholar

Wulan, A. J. and Simanjuntak, D. L. (2016) 'Faktor-Faktor yang Mempengaruhi Kejadian Neural Tube Defect', Majority, 5(3), pp. 55-61. Available at: http://juke.kedokteran.unila.ac.id/index.php/majority/article/view/1037/8 31. Google Scholar

First publication right:

Jurnal Syntax Fusion: Jurnal Nasional Indonesia

This article is licensed under:

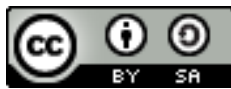

